\title{
Vanishing world: alkaline, saline lakes in Central Europe and their diatom assemblages
}

\author{
Csilla Stenger-Kovács, ${ }^{1 *}$ Edina Lengyel, ${ }^{2}$ Krisztina Buczkó, ${ }^{3}$ Franciska M. Tóth, ${ }^{4}$ Luciane O. Crossetti, ${ }^{5}$ Attila \\ Pellinger, ${ }^{6}$ Zsuzsa Zámbóné Doma, ${ }^{1}$ and Judit Padisák ${ }^{1,2}$ \\ ${ }^{1}$ University of Pannonia, Department of Limnology, Veszprém, Hungary \\ ${ }^{2}$ MTA-PE Limnoecology Research Group of the Hungarian Academy of Sciences, Veszprém, Hungary \\ ${ }^{3}$ Department of Botany, Hungarian Natural History Museum, Budapest, Hungary \\ ${ }^{4}$ Eötvös Loránd University, Department of Physical Geography, Geoinformatics Research Group, Budapest, Hungary \\ ${ }^{5}$ Universidade Federal do Rio Grande do Soul, Department of Ecology, Porto Alegre, Brasil \\ ${ }^{6}$ Fertö-Hanság National Park, Sarród, Hungary \\ *Corresponding author: stenger@almos.uni-pannon.hu
}

Received 27 December 2013; accepted 30 May 2014; published 16 September 2014

\section{Abstract}

European shallow, alkaline, saline lakes are potential indicators of climate change. Diatoms have often been reported as valuable proxies for different kinds of anthropogenic activities. Diatom assemblages and 14 environmental variables from shallow, alkaline lakes from 2 different regions of the Carpathian basin (Europe) were investigated for 3 years to (1) elucidate the physical and chemical parameters and diatom assemblages of these lakes, (2) select the principle variables affecting the diatom communities, and (3) show the relevance of diatoms as ecological bioindicators. Water chemical characteristics of the lakes in the 2 regions differ significantly in anion concentrations $\left(\mathrm{HCO}_{3}^{-}, \mathrm{SO}_{4}{ }^{2-}\right.$, and $\mathrm{Cl}^{-}$), platinum (Pt) units (colour), and oxygen saturation. Dominance by the stress-tolerant, motile diatom ecological guild, represented mainly by Nitzschia and Navicula species, was characteristic in these saline, turbid environments. Indicator species of the 2 regions were found to be different. Diatom assemblage composition was chiefly determined by conductivity and $\mathrm{HCO}_{3}{ }^{-}$and $\mathrm{SO}_{4}{ }^{2-}$ concentrations. Nutrient loads, extreme weather events, and consequences of habitat maintenance management were unequivocally identifiable by variations in the benthic diatom assemblage composition. Diatoms are valuable indicators for assessment of ecological status of these saline, alkaline lakes. Including these organisms in ecological status assessments of inland saline lakes may improve the effectiveness of directives for conservation management and might be useful in preserving these pristine habitats that depend on natural hydrological processes.

Key words: climate, diatoms, maintenance, management, saline lakes, status

\section{Introduction}

Endorheic, saline lakes are typically small $(<50 \mathrm{ha})$ and shallow $(<1 \mathrm{~m})$. Their total area on the globe is large $(0.006 \%$ of the total global water; Williams 1986$)$, and their volume is not markedly different from that of inland freshwaters (0.007\%; Shiklomanov 1990, Williams 1993). Most are found in arid and semiarid regions (Williams 2002). Their physical and chemical features depend on the local geomorphology, basin characteristics (Dargám
1995), geochemistry (Simon et al. 2011), and evaporation and precipitation (Langbein 1961). Lakes are relatively closed systems compared to running waters or terrestrial habitats and are therefore excellent sensors of environmental changes (Gottschalk and Kahlert 2012). Saline lakes are sensitive to unpredictable weather and climate changes (e.g., rainfall, UV radiation). Even relatively small variations cause large, even irreversible changes in the natural character of salt lakes (Hammer 1990). The ephemeral nature of these lakes results in a wide range of 
salinity and a reduction in diversity (Moss 1994). Saline lakes have largely been neglected in recent limnological and hydrobiological research (Moss 1994).

Despite the economic and noneconomic value of these lakes, only a few are subjected to active conservation (Williams 1993). Climate change and catchment activities such as water course diversion, dredging, or excessive pumping of surface freshwater or ground water threaten their "good" ecological status (Williams 2002). In the Carpathian Basin, $90 \%$ of these waterbodies are found in protected areas (national parks); additionally, each alkaline, saline lake is under ex lege protection (by law). Pannonic saline steppes and marshes (Natura 2000 areas) are especially threatened by the lowering water table due to groundwater withdrawal, loss of periodic spring floods, and excessive drainage of the surrounding areas (VGT 2009). In the last few decades, the number of these distinctive, alkaline habitats has decreased in Hungary and Austria and are now restricted to only 2 regions: the Danube-Tisza Interfluve and the Fertö-Hanság regions (Boros 1999). A similar phenomenon was observed in Mexico and Spain (Alcocer and Escobar 1990). According to predictions, the extent of these seasonally filled saline lakes will further decrease by 2025 due to human-induced climate change (Williams 2002).

Diatoms commonly occur in saline and alkaline saline lakes (De Deckker 1988). Benthic diatoms can be found in considerable quantities in East African saline lakes (Gasse 1986a) where they are not light limited (Tuite 1981). In this type of lake in Bolivia, the algal biomass is dominated by diatoms (Servant-Vildary 1984). In a Romanian study on anthroposaline lakes (Ionescou et al. 1998), half of the identified algal taxa were diatoms. Despite their importance, there have been few studies on the ecology of these organisms. In contrast with the United States, South America, Africa, and Australia (Williams 1986), only sporadic or unpublished data are available on diatoms of saline lakes in Eurasia. Recognition of diatoms as useful indicator species of environmental changes initiated intensive research in the 1980s and 1990s (e.g., Hammer et al. 1983, Bradbury et al. 1989, Blinn 1990). Most of these published diatom studies on saline lakes were paleolimnological reconstructions (e.g., Gasse et al. 1997, Reed 1998), however, because preserved diatoms as proxies are applicable to reconstructing changes in salinity, ice cover, and water level (Spaulding and McKnight 1999, Fritz et al. 2010). Early publications on diatoms of inland saline lakes were mainly floristic (Hustedt 1959, Grunow 1862), and such works continued to appear (e.g., Grimes and Rushforth 1982, Sabbe et al. 2003). Ecological investigations of recent benthic/ planktonic diatom assemblages are sporadic, not only in Europe (Padisák and Dokulil 1991, 1994, Buczkó and Ács
1996-1997, Nagy et al. 2008), but also on other continents (Sze and Kingsbury 1972, Blinn 1993).

Based on theory (Bhattacharyya and Volcani 1980), salinity may have only an indirect effect on diatom distribution by affecting thickness of the silica wall (Tuchmann et al. 1984) and pore size (Leterme et al. 2013). Specific surface area and pore size decrease with salinity (Vrieling et al. 2007, Leterme et al. 2010), influencing nutrient transport across the cell membrane and other physiological processes (Fritz et al. 2010). Salinity significantly affects the valve morphology of diatoms (Trobajo et al. 2011), and these morphological features may indicate changes of environmental drivers (Trobajo et al. 2004). Morphological plasticity of diatoms might also explain their ecological success in extreme environments (Leterme et al. 2013). Some species are associated with a given anion (e.g., Cymbella pusilla to bicarbonate because of its higher carbon requirement, or Chaetoceros elmorei to sulphate; Saros and Fritz 2002). Physiological or physiochemical processes determine these specializations because high salinity physioecologically excludes a number of species without osmoregulatory mechanisms and, consequently, their related traits (De Deckker 1988). The ionic concentration-dependent distributions have not been well studied (Saros and Fritz 2000). Accordingly, one of the recent goals of diatom research is to understand the diatom-salinity relationship using quantitative analyses of diatom distribution (Potapova 2011).

In Hungary, most diatom studies have focused on the 3 biggest, shallow, saline lakes: Lake Velencei (surface area 2600 ha, mean water depth $1.5 \mathrm{~m}$ ), Lake Fertö/Neusiedlersee (surface area 30900 ha, mean depth $0.7-1.5 \mathrm{~m}$ ), and Lake Szelidi (surface area 360 ha, mean depth $3.5 \mathrm{~m}$; Pantocsek 1912, Donászy et al. 1959, Szemes 1959, Buczkó 1986, Ács et al. 1991). Several algological studies (mostly of phytoplankton) of these soda pans were published (e.g., Kiss 1976, Padisák 1999, Fehér and Schmidt 2003, Fehér 2010), and some studies addressed the diatom floras, or at least included some records of diatom species (Grunow 1860, 1863, Cholnoky 1929, Uherkovich 1965, 1969, 1970, Kiss 1971, 1974, 1975, 1978, Schmidt and Fehér 1996). With the recognition of the scientific and conservation values of these alkaline lakes, a number of studies have recently been initiated to understand the hydrogeology (Simon et al. 2011), water chemistry (Boros 1999), bacterial communities (Rusznyák et al. 2011, Borsodi et al. 2013), picoplankton (Somogyi et al. 2011a, 2011b, 2012, Kürthy et al. 2012, Pálffy et al. 2013), zooplankton (Horváth et al. 2013a), macroinvertebrates (Horváth et al. 2013b), and waterfowl (Boros et al. 2008). Information on their benthic diatom communities and their ecology has remained scarce, however. Water chemical and biological characteristics of alkaline, saline 
lakes would provide the ecological basis for their management, and the use of benthic diatoms as bioindicators to assess their ecological status and the impact of climate change is promising.

The aim of this study was to determine (1) physical and chemical characteristics and (2) diatom assemblages of shallow, saline, alkaline lakes located in 2 different regions (Fertö-Hanság and Danube-Tisza Interfluve) in the Carpathian basin (Europe); (3) to determine the principle variables that significantly affect the diatom communities in these special environments; and (4) to provide directives for ecological and conservation management.

\section{Methods and materials}

Samples for water chemistry and analysis of benthic diatoms were collected from 31 small, shallow, alkaline, saline lakes from 2 different parts of the "Hungarian lowlands" ecoregion (the $11^{\text {th }}$ ecoregion of European lakes and rivers): (1) Fertö-Hanság (FH; distributed in Austria and Hungary) and (2) Danube-Tisza Interfluve (DT; in Hungary; Fig. 1; Table 1) in 3 different years (2006, 2008, and 2012). Following the recommendations for sampling littoral diatoms in lakes (King et al. 2006), 96 diatom samples were collected from macrophytes and mud, which represent the natural substrate type in these lakes. In 2006, sampling was conducted only in spring, the season when these lakes reach their maximum water volume. In 2008, sampling was extended to autumn, and in some cases in 2012, we could sample even in winter (Table 1).

Diatoms were removed from macrophytes with a toothbrush, and mud surface was sampled with a pipette. For analyses of siliceous algae, samples were prepared using standard digestion procedures (CEN 2003), then valves were embedded in Zrax. To determine the relative abundance of the species and diatom ecological guilds, a minimum of 400 valves per slide was counted using a Zeiss Axio Imager A1 with Planapochromat DIC lense at $1000 \times$ magnification. Small, difficult taxa were investigated with a Hitachi S-2600 N scanning electron

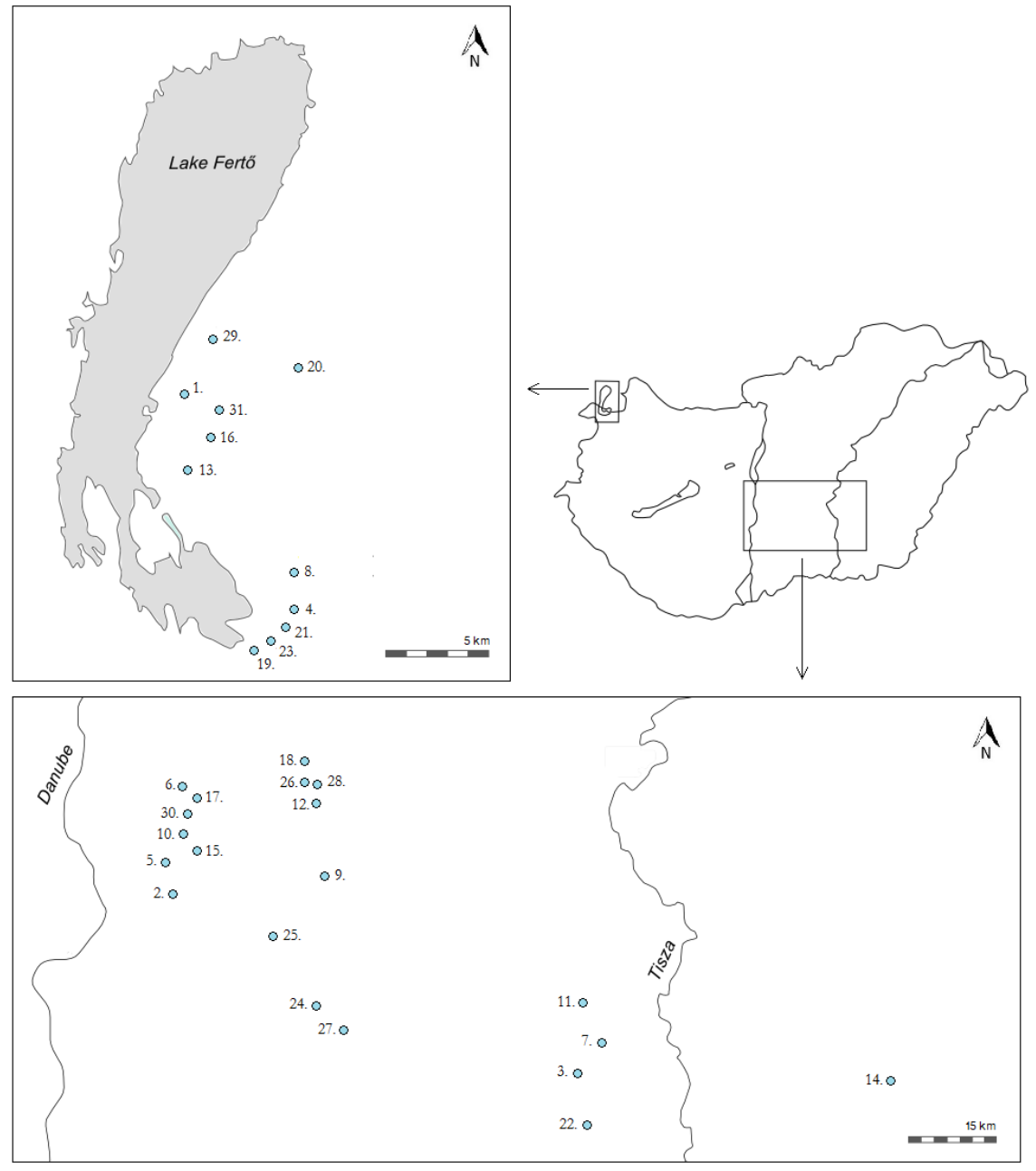

Fig. 1. Saline, alkaline lakes sampled from the 2 regions (lake numbers in Table 1). 
Table 1. The investigated saline, alkaline lakes, their country, region $(\mathrm{FH}=$ Fertö- Hanság, DT = Danube- Tisza Interfluve), GPS coordinates, number of samples, and sampling year and season $(\mathrm{S}=$ spring, $\mathrm{SU}=$ summer, $\mathrm{A}=$ autumn, $\mathrm{W}=$ winter $)$.

\begin{tabular}{|c|c|c|c|c|c|c|c|}
\hline Saline Lakes & Country & Region & GPS coc & dinates & Samples & Year & Season \\
\hline 1. Albersee & Austria & $\mathrm{FH}$ & $47^{\circ} 46.449 \mathrm{~N}$ & $16^{\circ} 46.177 \mathrm{E}$ & 2 & 2008 & $S$ \\
\hline 2. Bába-szék & Hungary & DT & $46^{\circ} 44.431 \mathrm{~N}$ & $19^{\circ} 09.019 \mathrm{E}$ & 5 & 2006,2008 & $\mathrm{~S}, \mathrm{~A}$ \\
\hline 3. Bíbic-tó & Hungary & DT & $46^{\circ} 28.105 \mathrm{~N}$ & $19^{\circ} 58.487 \mathrm{E}$ & 1 & 2006 & S \\
\hline 4. Borsodi-dűlő & Hungary & FH & $47^{\circ} 40.891 \mathrm{~N}$ & $16^{\circ} 50.401 \mathrm{E}$ & 13 & 2008,2012 & $\mathrm{~S}, \mathrm{~A}, \mathrm{~W}$ \\
\hline 5. Böddi-szék & Hungary & DT & $46^{\circ} 45.389 \mathrm{~N}$ & $19^{\circ} 08.373 \mathrm{E}$ & 4 & 2006,2008 & $\mathrm{~S}, \mathrm{SU}$ \\
\hline 6. Büdös-szék & Hungary & DT & $46^{\circ} 51.577 \mathrm{~N}$ & $19^{\circ} 10.943 \mathrm{E}$ & 1 & 2006 & S \\
\hline 7. Büdös-szék Pusztaszer & Hungary & DT & $46^{\circ} 32.465 \mathrm{~N}$ & $20^{\circ} 15.815 \mathrm{E}$ & 1 & 2006 & $\mathrm{~S}$ \\
\hline 8. Cikes & Hungary & FH & $47^{\circ} 41.763 \mathrm{~N}$ & $16^{\circ} 50.459 \mathrm{E}$ & 3 & 2008 & $\mathrm{~S}$ \\
\hline 9. Csárda-szék & Hungary & DT & $46^{\circ} 45.326 \mathrm{~N}$ & $19^{\circ} 27.394 \mathrm{E}$ & 1 & 2006 & S \\
\hline 10. Fehér-szék & Hungary & DT & $46^{\circ} 48.284 \mathrm{~N}$ & $19^{\circ} 11.159 \mathrm{E}$ & 1 & 2006 & S \\
\hline 11. Fülöp-szék & Hungary & DT & $46^{\circ} 55.447 \mathrm{~N}$ & $19^{\circ} 99.420 \mathrm{E}$ & 1 & 2006 & S \\
\hline 12. Hattyús-szék & Hungary & DT & $46^{\circ} 52.522 \mathrm{~N}$ & $19^{\circ} 26.350 \mathrm{E}$ & 1 & 2006 & S \\
\hline 13. Herrnsee & Hungary & FH & $47^{\circ} 44.609 \mathrm{~N}$ & $16^{\circ} 46.210 \mathrm{E}$ & 3 & 2008 & S \\
\hline 14. kardoskúti Fehértó & Hungary & DT & $46^{\circ} 28.245 \mathrm{~N}$ & $20^{\circ} 37.819 \mathrm{E}$ & 4 & 2006,2008 & $\mathrm{~S}, \mathrm{SU}$ \\
\hline 15. Kelemen-szék & Hungary & DT & $46^{\circ} 47.504 \mathrm{~N}$ & $19^{\circ} 10.591 \mathrm{E}$ & 4 & 2006,2008 & S \\
\hline 16. Kirchsee & Hungary & FH & $47^{\circ} 45.443 \mathrm{~N}$ & $16^{\circ} 47.299 \mathrm{E}$ & 3 & 2008 & S \\
\hline 17. Kisréti-tó & Hungary & DT & $46^{\circ} 86.790 \mathrm{~N}$ & $19^{\circ} 19.360 \mathrm{E}$ & 1 & 2006 & S \\
\hline 18. Kondor-tó & Hungary & DT & $46^{\circ} 53.471 \mathrm{~N}$ & $19^{\circ} 25.068 \mathrm{E}$ & 1 & 2006 & $\mathrm{~S}$ \\
\hline 19. Legény-tó & Hungary & $\mathrm{FH}$ & $47^{\circ} 39.793 \mathrm{~N}$ & $16^{\circ} 48.802 \mathrm{E}$ & 12 & 2008,2012 & $\mathrm{~S}, \mathrm{~A}, \mathrm{~W}$ \\
\hline 20. Neubruch & Austria & FH & $47^{\circ} 47.162 \mathrm{~N}$ & $16^{\circ} 50.655 \mathrm{E}$ & 3 & 2008 & S \\
\hline 21. Nyéki-szállás & Hungary & FH & $47^{\circ} 40.623 \mathrm{~N}$ & $16^{\circ} 49.970 \mathrm{E}$ & 7 & 2006,2008 & $\mathrm{~S}, \mathrm{SU}, \mathrm{A}$ \\
\hline 22. Ösze-szék & Hungary & DT & $46^{\circ} 24.612 \mathrm{~N}$ & $19^{\circ} 59.418 \mathrm{E}$ & 1 & 2006 & S \\
\hline 23. Paprét & Hungary & FH & $47^{\circ} 39.943 \mathrm{~N}$ & $16^{\circ} 49.597 \mathrm{E}$ & 6 & 2008,2012 & $\mathrm{~S}, \mathrm{~A}$ \\
\hline 24. pirtói Nagy-tó & Hungary & DT & $46^{\circ} 31.623 \mathrm{~N}$ & $19^{\circ} 28.189 \mathrm{E}$ & 1 & 2006 & $\mathrm{~S}$ \\
\hline 25. Sárkány-tó & Hungary & DT & $46^{\circ} 44.481 \mathrm{~N}$ & $19^{\circ} 23.216 \mathrm{E}$ & 1 & 2006 & S \\
\hline 26. Szappan-szék & Hungary & DT & $46^{\circ} 53.471 \mathrm{~N}$ & $19^{\circ} 25.068 \mathrm{E}$ & 1 & 2006 & S \\
\hline 27. Szarvas-tó & Hungary & DT & $46^{\circ} 32.774 \mathrm{~N}$ & $19^{\circ} 29.012 \mathrm{E}$ & 1 & 2006 & S \\
\hline 28. Szívós-szék & Hungary & DT & $46^{\circ} 52.751 \mathrm{~N}$ & $19^{\circ} 26.467 \mathrm{E}$ & 1 & 2006 & S \\
\hline 29. Untersee & Austria & FH & $47^{\circ} 48.096 \mathrm{~N}$ & $16^{\circ} 47.051 \mathrm{E}$ & 3 & 2008 & $\mathrm{~S}$ \\
\hline 30. Zab-szék & Hungary & DT & $46^{\circ} 50.150 \mathrm{~N}$ & $19^{\circ} 10.112 \mathrm{E}$ & 6 & 2008 & A \\
\hline 31. Zicklacke & Austria & FH & $47^{\circ} 46.075 \mathrm{~N}$ & $16^{\circ} 46.870 \mathrm{E}$ & 3 & 2008 & $\mathrm{~S}$ \\
\hline$\Sigma 31$ & $\Sigma 2$ & $\Sigma 2$ & & & $\Sigma 96$ & $\Sigma 3$ & $\Sigma 4$ \\
\hline
\end{tabular}

microscope. Sorting species into high-profile, low-profile, and motile guilds followed the description by Cox (1996), Passy (2007), Rimet and Bouchez (2011), and StengerKovács et al. (2013).

Dissolved oxygen, oxygen saturation, conductivity, $\mathrm{pH}$, and temperature were measured in situ with an HQ40d Hach Lange multimeter at the sampling site. In laboratory analyses, concentrations of nitrogen and phosphorus forms were measured: nitrate $\left(\mathrm{NO}_{3}^{-}\right)$by the UV spectrophotomet- ric screening method; ammonium $\left(\mathrm{NH}_{4}^{+}\right)$by the phenate method; soluble reactive phosphorus (SRP) and total phosphorus (TP) by the colorimetric method (APHA 1998); soluble reactive silica (SRSi) by the spectrophotometric method (Wetzel and Likens 2000); and chemical oxygen demand (COD) by the closed refluxe, titrimetric method (APHA 1998). The intensity of the brown colour in platinum (Pt) units used to assess the amount of humic substances was determined according to Cuthbert and del Giorgio (1992). 
The $t$-test for unequal variances (Welch-probe) was used (1) to examine whether the lakes in the 2 regions ( $\mathrm{FH}$ and DT) had different water chemistry and (2) to categorize the assemblages by guilds and identify the most characteristic diatom ecological guilds in all of the samples and in the 2 regions, separately. The Indicator Species Analysis (IndVal; Dufrêne and Legendre 1997) based on abundance values and relative frequency of occurrence (Legendre and Legendre 1998) was applied to identify species that can be used to separate FH and DT. For model building, a forward selection procedure of the redundancy analyses (RDA; Blanchet et al. 2008) was applied to identify master variables having the most significant effect on the diatom community composition and to reduce the number of the explanatory parameters. The stepping order of the environmental parameters to the model was based on the Akaike information criterion (AIC) with $p$-values $(<0.05)$. The significance of all terms was assessed by ANOVA permutation test (permutations $=199, p<0.05$ ). Before the RDA analyses, species abundance data were Hellingertransformed (Legendre and Legendre 1998) to reduce the significance of the most abundant species, a suggested method for multivariate approaches of compositional data containing a number of zero values (Legendre and Gallagher 2001). Rare species (occurrence $<3$ sampling sites) or species with small relative abundance $(<5 \%$ in the total dataset) were excluded from the ordination analyses. Environmental variables were also transformed (see Table 2) to reach the normal distribution of the data; the best transformation of the individual variables was selected. All statistical analyses were performed in $\mathrm{R}$ computing environment (R 2.11.0; R Development Core Team 2010); model building was conducted using the package "Vegan" (Oksanen et al. 2012).

\section{Results}

The average conductivity of the lakes was $>4000 \mu \mathrm{S} \mathrm{cm}^{-1}$, with a maximum conductivity of $17600 \mu \mathrm{S} \mathrm{cm}^{-1}$. All lakes were alkaline, with an average $\mathrm{pH}$ of 8.9. The most abundant anion was bicarbonate $\left(\mathrm{HCO}_{3}^{-}\right.$, average concentration $\left.941 \mathrm{mg} \mathrm{L}^{-1}\right)$, followed by sulfate $\left(\mathrm{SO}_{4}{ }^{2-}\right.$, average $\left.735 \mathrm{mg} \mathrm{L}^{-1}\right)$, and chloride $\left(\mathrm{Cl}^{-}\right.$, average $\left.226 \mathrm{mg} \mathrm{L}^{-1}\right)$. Nutrient ( $\mathrm{N}$ and $\mathrm{P}$ forms) concentrations, especially those for TP were high (average $1989 \mu \mathrm{g} \mathrm{L}^{-1}$ ). Water temperatures varied between 5.3 and $36{ }^{\circ} \mathrm{C}$, depending on the seasonal and daily variance of the air temperature. The water was usually oversaturated with oxygen (average $112 \%$ ); the average COD was $43 \mathrm{mg} \mathrm{L}^{-1}$ (Table 2). Comparison of the chemical and physical features of the lakes in the 2 regions (Welch-test) identified several significant differences: $\left.\mathrm{HCO}_{3}^{-}(p<0.001), \mathrm{Cl}^{-} p=0.009\right)$ ions, Pt colour $(p=0.025)$, and $\operatorname{COD}(p=0.013)$ were higher in the lakes of the DT (Table 2). In the $\mathrm{FH}, \mathrm{SO}_{4}{ }^{2-}$ concentration $(p<0.001)$ and oxygen saturation $(135 \%$, $p=0.010$; Table 2) were higher than in DT.

The dominant diatom species were the members of the genera Nitzschia and Navicula of the motile diatom ecological guild. Of the 174 identified species, 107 were motile, 37 high profile, and 30 low profile. In the FH region, 120 species were found (81 motile, 21 low profile, and 18 high profile), similar to the DT, where 112 species were identified (68 motile, 13 low profile, and 31 high profile; Fig. 2). Based on the absolute numbers (Fig. 2a) and relative abundances (Fig. 2b) of species in the different ecological guilds, statistically significant differences were found between the high-profile and motile guilds $(p<0.001)$ and between low-profile and motile guilds $(p<0.001)$ on both the regional and whole sample sets (Fig. 2). No significant differences were found between the high- and low-profile guilds.
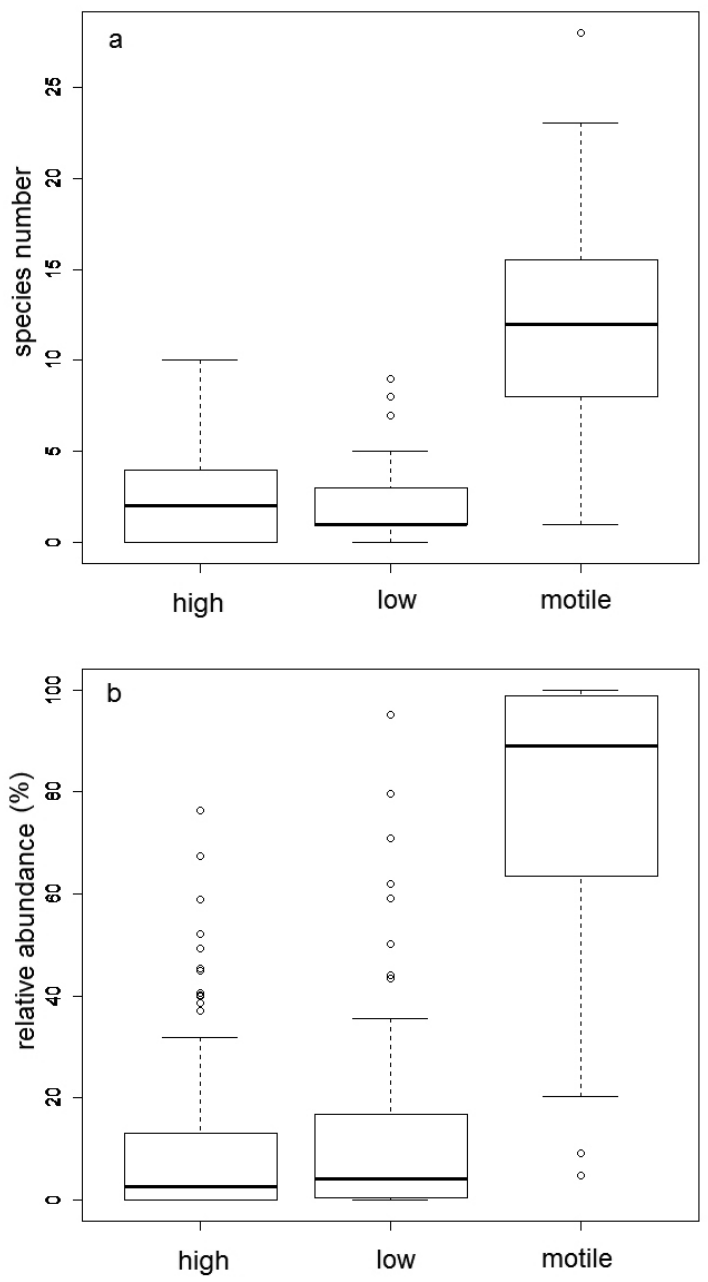

Fig. 2. Boxplots of the different diatomic ecological guilds based on (a) the number and (b) relative abundance of the species (high $=$ high-profile guild, low $=$ low-profile guild, motile $=$ motile guild $)$ in all lakes. 
Table 2. Physical and chemical parameters and their differences based on Welch-test of the saline, alkaline lakes in the 2 regions, the DanubeTisza Interfluve and the Fertö-Hanság.

\begin{tabular}{|c|c|c|c|c|c|c|c|c|c|c|c|}
\hline \multirow[b]{2}{*}{ variables } & \multirow[b]{2}{*}{ units } & \multirow[b]{2}{*}{ transformations } & \multicolumn{4}{|c|}{ Danube-Tisza Interfluve $(n=34)$} & \multicolumn{4}{|c|}{ Fertô-Hanság $(n=25)$} & \multirow{2}{*}{$\begin{array}{c}\text { Welch-test } \\
\text { p-value }\end{array}$} \\
\hline & & & mean & SD & $\min$ & $\max$ & mean & SD & $\min$ & $\max$ & \\
\hline conductivity & $\mu \mathrm{s} \mathrm{cm}{ }^{-1}$ & $\mathrm{x}^{\prime}=\ln (\mathrm{x}+1)$ & 4697 & 3808 & 520 & 17600 & 4318 & 2716 & 1765 & 13650 & ns \\
\hline $\mathrm{pH}$ & & - & 8.9 & 0.4 & 8.1 & 9.7 & 8.9 & 0.4 & 8.3 & 9.4 & ns \\
\hline $\mathrm{SO}_{4}^{2-}$ & $m g L^{-1}$ & $\mathrm{x}^{\prime}=\ln (\mathrm{x}+1)$ & 118.9 & 140.0 & 0.0 & 731.0 & 616.4 & 593.8 & 91.9 & 2433.0 & $<0.001$ \\
\hline $\mathrm{HCO}_{3}^{-}$ & $\mathrm{mg} \mathrm{L}^{-1}$ & $x^{\prime}=\ln (x+1)$ & 1182.4 & 508.4 & 435.0 & 2092.0 & 700.3 & 326.5 & 291.3 & 1866.6 & $<0.001$ \\
\hline $\mathrm{Cl}^{-}$ & $\mathrm{mg} \mathrm{L}^{-1}$ & $x^{\prime}=\ln (x+1)$ & 325.9 & 374.5 & 0.9 & 1568.9 & 125.5 & 181.4 & 3.4 & 819.4 & 0.009 \\
\hline colour & $\mathrm{mg} \mathrm{L}^{-1} \mathrm{Pt}$ & - & 525.0 & 276.2 & 243.1 & 926.9 & 96.6 & 72.7 & 40.9 & 352.2 & 0.025 \\
\hline $\mathrm{NH}_{4}^{+}$ & $m g L^{-1}$ & $\mathrm{x}^{\prime}=\arcsin \left(\mathrm{x}^{0.5}\right)$ & 2.5 & 6.8 & 0.0 & 32.7 & 2.5 & 5.4 & 0.0 & 25.9 & ns \\
\hline $\mathrm{NO}_{3}^{-}$ & $\mathrm{mg} \mathrm{L}^{-1}$ & $x^{\prime}=(x / 100)^{0,5}$ & 1.8 & 2.0 & 0.3 & 9.9 & 1.0 & 1.7 & 0.0 & 7.6 & $\mathrm{~ns}$ \\
\hline SRP & $\mu \mathrm{g} \mathrm{L}^{-1}$ & $x^{\prime}=\ln (x+1)$ & 661.9 & 831.6 & 10.0 & 2985.0 & 354.8 & 449.9 & 6.3 & 1530.0 & ns \\
\hline TP & $\mu \mathrm{g} \mathrm{L}^{-1}$ & $x^{\prime}=\ln (x+1)$ & 2064.9 & 3954.4 & 50.0 & 21760.0 & 1913.1 & 3249.4 & 43.9 & 14720.0 & ns \\
\hline SRSi & $\mathrm{mg} \mathrm{L}^{-1}$ & $x^{\prime}=\ln (x+1)$ & 5.4 & 5.5 & 0.1 & 29.6 & 4.1 & 2.8 & 0.2 & 12.2 & ns \\
\hline temperature & ${ }^{\circ} \mathrm{C}$ & - & 18.6 & 6.4 & 5.3 & 36.0 & 21.7 & 9.2 & 7.4 & 35.4 & ns \\
\hline $\mathrm{O}_{2}$ saturation & $\%$ & - & 89.8 & 44.4 & 1.2 & 184.2 & 135.0 & 71.8 & 18.1 & 293.9 & 0.010 \\
\hline COD & $\mathrm{mg} \mathrm{L}^{-1} \mathrm{O}_{2}$ & $x^{\prime}=\ln (x+1)$ & 59.6 & 71.4 & 6.0 & 423.0 & 26.4 & 18.3 & 0.0 & 72.0 & 0.013 \\
\hline
\end{tabular}

The indicator species analysis identified 5 indicator species with significant indicator values for the DT region (Table 3); Nitzschia fonticola (Grunow) Grunow and Mayamaea atomus var. permitis (Hustedt) Lange-Bertalot had the highest indicator values (IndVal $=25.90$ and 20.70 , respectively). Of the 16 indicator species in the FH region, Navicymbula pusilla (Grunow) Krammer, Anomoeoneis sphaerophora Pfitzer, Nitzschia solita Hustedt, and Rhoicosphenia abbreviata (C.Agardh) Lange-Bertalot had the highest indicator values (IndVal = 46.30, 41.20, 33.30 and 33.30, respectively; Table 3).

According to the RDA, separation of the 2 regions was most strongly determined by (Fig. 3a and 3c) $\mathrm{HCO}_{3}{ }^{-}$, $\mathrm{SO}_{4}{ }^{2-}, \mathrm{COD}$, and $\mathrm{NO}_{3}{ }^{-}$along Axis 1 (10.3\%; Fig. 3b). Along Axis 2 (9.8\%), samples were grouped based mainly by $\mathrm{Cl}^{-}$and TP concentrations (Fig. 3b). In the DT, one of the groups (DT1) included samples with higher $\mathrm{NO}_{3}{ }^{-}$and $\mathrm{Cl}^{-}$concentrations (Fig. 3c), in contrast to the second group (DT2), which was characterized by higher conductivity, SRP, TP, $\mathrm{NH}_{4}^{+}$concentrations, $\mathrm{pH}$, and temperature (Fig. 3b). In group DT1, Nitzschia supralitorea Lange-Bertalot and Craticula halophila (Grunow) D.G. Mann dominated, while in group DT2 Nitzschia austriaca Hustedt and N. etoshensis Cholnoky were characteristic (Fig. 3d). In the FH region, 2 groups were also distinguished. Group 1 (FH1) was characterized by high $\mathrm{Cl}^{-}$and SRSi concentrations (Fig. 3b) with the following species (Fig. 3d): Entomoneis paludosa var. subsalina (Cleve) Krammer, Nitzschia palea (Kützing) W. Smith, N. paleaceae (Grunow in Cleve \& Grunow) Grunow in
Van Heurck, N. constricta (Gregory) Grunow, and Achnanthidium minutissimum (Kützing) Czarnecki. Group 2 (FH2) was characterized by higher $\mathrm{SO}_{4}{ }^{2-}$ concentrations and oxygen saturation (Fig. 3b), with assemblages dominated by Nitzschia aurariae Cholnoky, $N$. frustulum (Kützing) Grunow in Cleve \& Grunow, and Fallacia pygmaea (Kützing) A.J. Stickle \& D.G. Mann Fig. 3d). After the performance of the forward selection procedure in the reduced RDA model, 12 of the 13 environmental variables that had a significant effect on the diatom composition remained; only SRP was eliminated. The significance of the variables in descending order was: conductivity, $\mathrm{HCO}_{3}^{-}, \mathrm{SO}_{4}{ }^{2-}$, temperature, $\mathrm{COD}, \mathrm{TP}, \mathrm{pH}$, oxygen saturation, $\mathrm{NH}_{4}^{+}, \mathrm{SRSi}, \mathrm{NO}_{3}^{-}$, and $\mathrm{Cl}^{-}$.

\section{Discussion}

\section{Water chemistry}

The conductivity values (maximum $17600 \mu \mathrm{S} \mathrm{cm} \mathrm{cm}^{-1}$ ) recorded in these saline alkaline lakes did not reach the previously reported maximum values $\left(>30000 \mu \mathrm{S} \mathrm{cm}^{-1}\right.$; Schmidt 2003). Total ionic concentrations calculated from conductivity values according to Boros and Vörös (2010) varied between 416 (corresponding to freshwater; Hammer 1986) and $14080 \mathrm{mg} \mathrm{L}^{-1}$ (average $3606 \mathrm{mg} \mathrm{L}^{-1}$ ), which falls into the hyposaline category (Hammer 1986). In contrast to seawaters, ionic composition was dominated by $\mathrm{HCO}_{3}^{-}, \mathrm{SO}_{4}^{2-}$, and $\mathrm{Cl}^{-}$. Their concentration changed significantly with the precipitation of salts during the 
Table 3. Most significant indicator species based on the Indicator Species Analyses (IndVal) using species abundance data for the DanubeTisza Interfluve and for the Fertö-Hanság regions.

\begin{tabular}{|c|c|c|c|c|c|}
\hline Regions & Species & Author & $\begin{array}{l}\text { Mean } \\
\text { abundance }\end{array}$ & $\begin{array}{l}\text { Observed } \\
\text { indicator } \\
\text { value (IndVal) }\end{array}$ & $\mathbf{p}$ \\
\hline \multirow[t]{5}{*}{ Danube-Tisza } & Fistulifera saprophila & $\begin{array}{l}\text { (Lange-Bertalot \& Bonik) } \\
\text { Lange-Bertalot }\end{array}$ & 0.39 & 9.50 & 0.030 \\
\hline & Fragilaria famelica & (Kützing) Lange-Bertalot & 0.07 & 13.00 & 0.015 \\
\hline & Mayamaea atomus var. permitis & (Kützing) Lange-Bertalot & 0.67 & 20.70 & 0.015 \\
\hline & Nitzschia communis & Rabenhorst & 0.16 & 18.40 & 0.020 \\
\hline & Nitzschia fonticola & (Grunow) Grunow & 0.37 & 25.90 & 0.005 \\
\hline \multirow[t]{16}{*}{ Fertő-Hanság } & Amphora libyca & Ehrenberg & 0.12 & 16.70 & 0.005 \\
\hline & Anomoeoneis sphaerophora & (Ehrenberg) Pfitzer & 0.58 & 41.20 & 0.005 \\
\hline & Cocconeis placentula var. lineata & (Ehrenberg) van Heurck & 0.02 & 11.10 & 0.050 \\
\hline & Cyclotella meneghiniana & Kützing & 0.60 & 16.70 & 0.005 \\
\hline & Cymbella cymbiformis & C.Agardh & 0.05 & 11.10 & 0.055 \\
\hline & Gyrosigma sp. & Hassal & 0.29 & 20.40 & 0.010 \\
\hline & Hippodonta capitata & $\begin{array}{l}\text { (Ehrenberg) Lange-Bertalot, } \\
\text { Metzeltin and Witkowski }\end{array}$ & 0.06 & 12.30 & 0.050 \\
\hline & Hippodonta hungarica & $\begin{array}{l}\text { (Grunow) Lange-Bertalot, } \\
\text { Metzeltin and Witkowski }\end{array}$ & 0.17 & 14.80 & 0.025 \\
\hline & Navicula salinarum & Grunow & 0.24 & 22.20 & 0.005 \\
\hline & Navicymbula pusilla & (Grunow) K.Krammer & 0.51 & 46.30 & 0.005 \\
\hline & Nitzschia elegantula & Grunow & 0.28 & 22.20 & 0.005 \\
\hline & Nitzschia salinarum & Grunow & 0.03 & 11.10 & 0.050 \\
\hline & Nitzschia solita & Hustedt & 0.34 & 33.30 & 0.005 \\
\hline & Rhoicosphenia abbreviata & (C. Agardh) Lange-Bertalot & 0.86 & 33.30 & 0.005 \\
\hline & Stauroneis wislouchii & V.S. Poretzky \& Anisimova & 0.09 & 16.70 & 0.010 \\
\hline & Surirella peisonis & Pantocsek & 0.08 & 18.80 & 0.020 \\
\hline
\end{tabular}

evaporative concentration, as also observed by Eugster and Jones (1979). According to Simon et al. (2011), ionic composition of individual saline, alkaline lakes is related to the chemistry of groundwater. The composition of the groundwater of the catchment area is more important in saline than in freshwater lakes, which collect their water from surface flow (Comín et al. 1999). In the DT, the bicarbonate ion was dominant; most of these lakes are of a sodium bicarbonate $\left(\mathrm{Na}^{+}-\mathrm{HCO}_{3}^{-}\right)$type (Boros and Vörös 2010), in contrast to the FH region, which is characterized by the dominance of the $\mathrm{SO}_{4}{ }^{2-}$ anion. $\mathrm{COD}$ and $\mathrm{Pt}$ colour were consistently higher in the DT region. Allochtonous organic substances are derived from decomposition of macrophytes and droppings (V.-Balogh et al. 2009, 2010). The lakes were oversaturated with oxygen due to photosynthetic activity of the algae because of the daytime sampling, but oxygen saturation is known to be low (16\%) at night (Vörös and Boros 2010), and significant fluctua- tions of saturated and unsaturated conditions may occur on a daily basis in these highly productive lakes (Wetzel 1983). Oversaturation was higher in the FH region (maximum 294\%), although it did not reach the highest recorded maximum of $499 \%$ in Kelemen-szék in the DT region (Vörös and Boros 2010).

\section{Diatom assemblages}

Nitzschia and Navicula species were the most frequent in the saline lakes of the 2 regions in the Carpathian basin. At the generic level, they are dominant and characteristic in nonmarine (athalassic) saline lakes (Gasse 1986a, 1986b, Servant-Vildery and Roux 1990, Blinn 1993, Tibby et al. 2007, Blanco et al. 2013). These genera and other representatives of the motile ecological guild were significantly more abundant than those from the other 2 guilds. The reason for their abundance is that species in 
soda pans must survive, either temporarily or permanently, and adapt to special conditions (Oren 1999) such as high salinity, high turbidity (Secchi-transparency of only a few centimeters; Horváth et al. 2013a), high nutrient concentrations, high daily temperature fluctuations (Vörös and Boros 2010), and ephemeral features (Cognetti and Maltagliati 2000). Under these conditions, the motile ecological guild has a competitive advantage over either the low- or the high-profile guilds. Parallel with increasing turbulence rates (Alvial et al. 2008) and decreasing underwater low irradiance levels, their contribution to the assemblages rises significantly (Stenger-Kovács et al. 2013) because of their ability to actively select the most suitable habitat (Passy 2007). Moreover, they are shade- tolerant taxa; the photoadaptational parameter $\left(\mathrm{I}_{\mathrm{k}}\right)$ of Nitzschia species is low (Padisák 2003). In addition, the motile guild largely prefers eutrophic and/or organically polluted waters and proliferates in nutrient-rich habitats (Passy 2007) such as the saline lakes in this study.

Indicator species of the regions were satisfactorily defined based on the IndVal analyses; suitable examples are Nitzschia communis for the DT region and Anomoeoneis sphaerophora for the FH region. A. sphaerophora indicated the saline type of lakes in the $\mathrm{FH}$ region by exhibiting a positive response to high $\mathrm{pH}$ and bicarbonate content (Blinn 1993). Cyclotella meneghiniana (indicator species of the FH region) is a suitable and well-known example of species that are physioecologically adapted to high salinity
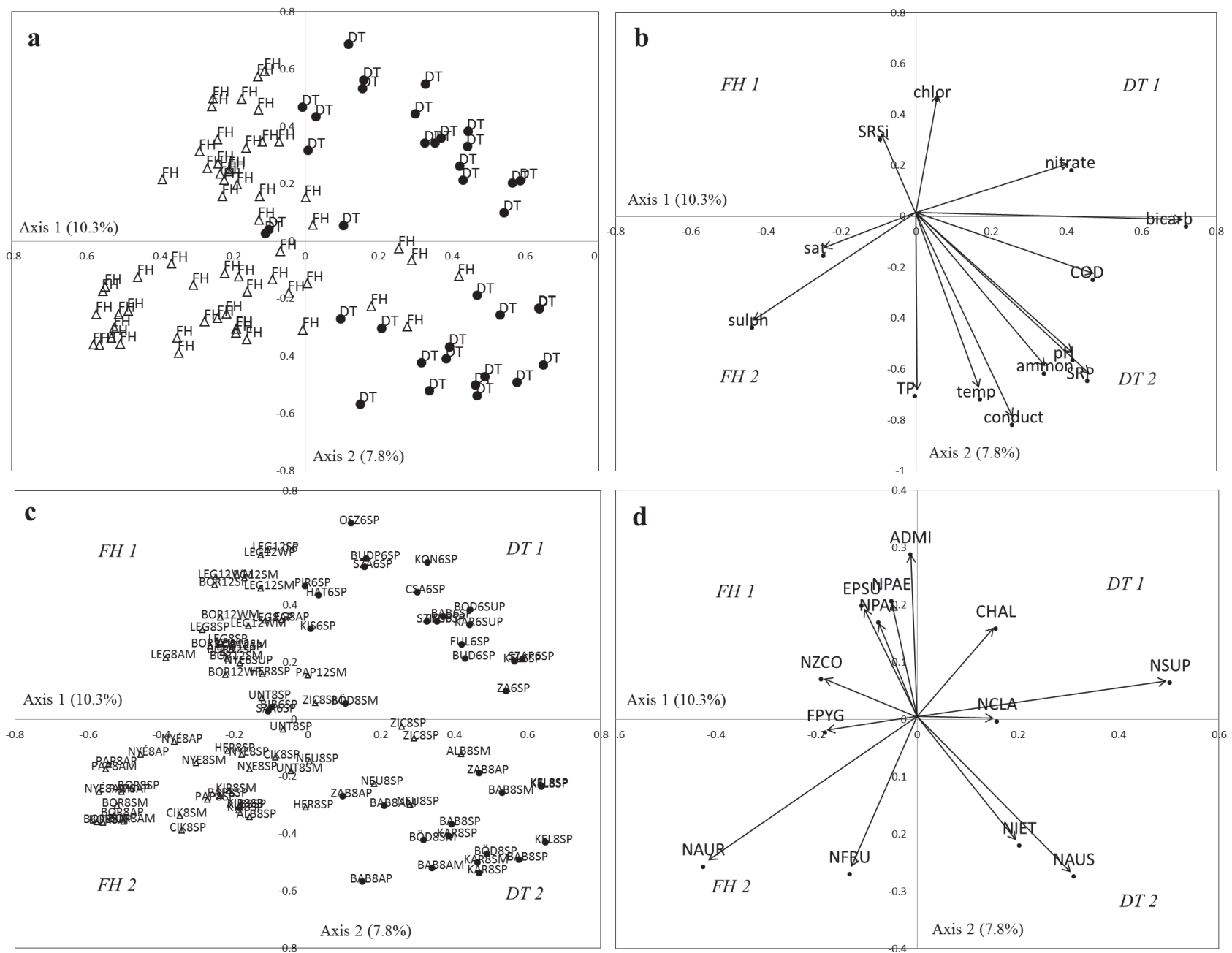

Fig. 3. Redundancy analyses (RDA) based on the water chemical and species abundance data emphasized (a) regions (Fertö-Hanság $=$ FH; Danube-Tisza Interfluve = DT); (b) explanatory variables (chlor $=$ chloride ion, bicarb $=$ bicarbonate, ammon $=$ ammonium, temp $=$ temperature, conduct $=$ conductivity, sulph $=$ sulphate, sat $=$ saturation); (c) samples (first 3 letters $=$ beginning of lake name; number $=$ year of sampling; next letter is season of sampling $[\mathrm{S}=$ spring, $\mathrm{SU}=$ summer, $\mathrm{A}=$ autumn, $\mathrm{W}=$ winter]; last letter is substrate type $[\mathrm{P}=$ macrophyte, $\mathrm{M}=$ mud]); and (d) dominant species. ADMI = Achnanthidium minutissimum, $\mathrm{CHAL}=$ Craticula halophila, EPSU $=$ Entomoneis paludosa var. subsalina, FPYG = Fallacia pygmaea, NAUR $=$ Nitzschia aurariae, NAUS $=$ Nitzschia austriaca, NZCO $=N$. constricta, NIET $=$ N. etoshensis, $\mathrm{NFRU}=N$. frustulum, $\mathrm{NPAL}=$ Nitzschia palea, $\mathrm{NPAE}=N$. paleaceae, $\mathrm{NSUP}=$ Nitzschia supralitorea . 
(De Deckker 1988) because they are able to synthetise osmoregulators (like proline). As salinity increases, proline synthesis rates and nitrogen demand also increase (Schobert 1974). In East African alkaline, saline lakes the most common species was Anomoeoneis sphaerophora, accompanied by Centrales and Navicula species (Tuite 1981). Nitzschia communis (indicator of DT region) was present in $63 \%$ of the saline lake habitats of western North America and had the highest specific conductance index values and tolerated the highest ionic strength (Blinn 1993).

In general, indicator species of the 2 regions marked not only high conductivity (e.g., Nitzschia fonticola for DT and Nitzschia salinarum for FH) but also eutrophic conditions (e.g., Fistulifera saprophila for DT, Hippodonta capitata for $\mathrm{FH}$ ). The high nutrient availability of these lakes is not necessarily the consequence of anthropogenic pollution; however, most are surrounded by agricultural areas and tilled down to their shorelines. Even so, because of the tens of thousands of birds that populate these lakes during migration (Harper et al. 2003, Boros et al. 2006, Horváth et al. 2013c) and the active maintenance of endemic beef cattle (Bos primigenius) and buffalo (Bubalus bubalis) farms in the regions, mammal and bird populations substantially increase plant nutrient levels through their droppings (Oduor and Schagerl 2007). The average TP concentration is 8 times higher $\left(1989 \mu \mathrm{g} \mathrm{L}^{-1}\right)$ compared to the freshwater lakes $\left(\sim 225 \mu \mathrm{g} \mathrm{L}^{-1}\right)$ of the ecoregion, whereas the average $\mathrm{NO}_{3}{ }^{-}$concentrations $\left(1.4 \mathrm{mg} \mathrm{L}^{-1}\right)$ exceed twice that of freshwater concentrations (based on the database of the University of Pannonia, unpublished data). Accordingly, resource availability prevails, with minimal competition for nutrients among the species (Oduor and Schagerl 2007).

\section{Main drivers of the diatom composition}

Using RDA, lakes were separated into 2 subgroups in each of the 2 regions based on $\mathrm{HCO}_{3}^{-}$concentration. Subgroup DT2 inside the DT region is characterized by pristine saline lakes (Kardoskúti-Fehértó, Böddi-szék, Bába-szék, Kelemen-szék), which are turbid soda ponds with high levels of suspended inorganic solids (Boros 1999, Váradi and Fehér 2010). Their conductivity, pH, and nutrient concentrations $\left(\mathrm{NH}_{4}^{+}, \mathrm{SRP}\right.$, and $\left.\mathrm{TP}\right)$ are the highest of all the investigated lakes. Their ecological status is the highest because their conditions are the closest to the status considered as natural. In this group, Nitzschia austriaca and Nitzschia etoshensis were dominant. Subgroup DT1 (e.g., Fülöp-szék, Büdös-szék, Csárda-szék, Ösze-szék) is characterized by higher concentrations of $\mathrm{Cl}^{-}$and $\mathrm{NO}_{3}^{-}$and includes only samples collected in 2006, which was a meteorologically exceptional year. High precipitation and flooding occurred in spring 2006; therefore, conductivity was lower and
$\mathrm{NO}_{3}{ }^{-}$concentration was higher than usual due to runoff from the surrounding agricultural areas. The lakes preserved their saline character, however; halophilic species like Nitzschia supralitorea and Craticula halophila were dominant. Nevertheless, changes in the ionic composition and in the dominant taxa clearly indicated the extreme weather conditions. The lakes in the DT area have a smaller surface area (e.g., Szappan-szék, Büdös-szék Pusztaszer) compared to those in other regions, which results in fewer waterfowl and lower TP.

Lakes in the $\mathrm{FH}$ region are characterized by lower bicarbonate content and can also be divided into 2 subgroups. Lakes in subgroup FH2 (e.g., Cikes, Pap-rét, Nyéki-szállás, Herrnsee, Albersee) are characterized by higher conductivity and dominated by $\mathrm{SO}_{4}{ }^{2-}$, with the diatom assemblages dominated by halophilic species like Nitzschia frustulum and $N$. aurariae. In addition to $\mathrm{SO}_{4}{ }^{2-}$, subgroup FH1 (Borsodi-dülö, Legény-tó) is dominated by $\mathrm{Cl}^{-}$and has a higher SRSi content; the conductivity and TP concentration in these lakes were lower. Subgroup FH1 mostly includes samples from Borsodi-dülö, which is located in the active reconstruction area of the national park. The water level is highly regulated, and therefore the characteristics of the water are modified and highly dependent on the management activities and conservation measures such as (1) flooding the area to supply water for the migratory birds and/or (2) draining the water through the established channel system of the FH to guarantee an adequate area for grazing of beef cattle and buffalo. Another example from this group is Legény-tó, which is in constant connection with a drainage system that maintains its permanent water level but considerably modifies its saline character. The lower TP concentration of the FH1 group is because most sampling occurred in winter when the water level was especially high and migratory waterfowl populations were reduced.

In the reduced RDA model, the explanatory variables determined by the composition of the diatom assemblage were, in descending order, conductivity, $\mathrm{HCO}_{3}{ }^{-}, \mathrm{SO}_{4}{ }^{2-}$, temperature, $\mathrm{COD}, \mathrm{TP}, \mathrm{pH}$, saturation, $\mathrm{NH}_{4}^{+}, \mathrm{SRSi}, \mathrm{NO}_{3}^{-}$, and $\mathrm{Cl}^{-}$. In Turkish saline lakes, temperature, carbonate, conductivity, $\mathrm{pH}$, silica, alkalinity, and SRP were the main environmental factors that explained variation in the diatom composition and the dominance of the assemblage by cosmopolitan species with high alkalinity tolerances (Koçer and Şen 2012). Except for SRP, this RDA model did not considerably reduce the number of the master variables. The statistically most significant factors were salinity $\left(\mathrm{HCO}_{3}{ }^{-}\right.$or $\left.\mathrm{SO}_{4}{ }^{2-}\right)$ and temperature. According to Williams (2002), conductivity and ionic composition determine the composition of biota, and these variables satisfactorily explained the differences in diatom assemblages of some Canadian lakes (Wilson et al. 1994). 
Temperature is a key factor that determines the existence of saline lakes (Williams 2002) as well as the diatom assemblages identified in this study. For Central Europe, climate scenarios predict a substantial $\left(6{ }^{\circ} \mathrm{C}\right)$ increase in temperature (Szépszó 2008) with modified precipitation patterns and increasing incidence of extreme weather events (high floods, heat waves, and droughts; Moss et al. 2009). The predicted effect of temperature increases or permanently higher summer water temperatures on diatom communities is not well understood. Some studies found that at temperatures $>34.2{ }^{\circ} \mathrm{C}$, diatoms are replaced by green algae as the dominant algae (Patrick 1969, Hickman 1982), or that the summerdominant epipelic diatom species required higher temperatures for rapid cell division than the species that are dominant during the cold seasons (Eloranta 1982, Admiraal et al. 1984).

Because high $\mathrm{pH}(8.1-9.4)$ is a characteristic feature of these lakes, its effect on the diatom assemblages cannot be neglected. Although diatoms are more sensitive to $\mathrm{pH}$ changes in acid-neutral than in alkaline lakes (Blinn 1993), response of the diatom community to $\mathrm{pH}$ in these lakes was pronounced. Both $\mathrm{pH}$ and oxygen concentration influence the nutrient availability of algae in hypereutrophic lakes (Sondergaard et al. 1990). Nutrient levels are less important in the studied lakes than in the lakes of the Kenyan Rift Valley, where importance order of the key variables was nitrate, conductivity, phosphorous, and light supply (Oduor and Schagerl 2007).

In summary, diatoms of these saline lakes proved to be good indicators of climate-driven variables such as salinity, ionic composition (Saros and Fritz 2002), and temperature, as well as anthropogenic activities, including when these activities serve nature conservation purposes.

\section{Management}

Before water regulation, floods of the River Danube and River Tisza supplied the small saline lakes of the DT. At present, solely precipitation and groundwater provide their water supply. The scarcity of water in the DT has long been evident (VGT 2009) due to climate change and anthropogenic interventions (watercourse regulation, excessive drainage, and overpumping of groundwaters). Today the situation is critical. The area of lakes has decreased, some lakes have completely or partly dried out (e.g., Szappan-szék), and both abundance and diversity of biota have decreased.

There is an urgent need to assess lake values, to characterize threats, and to suggest management and conservation measures (Williams 2002). The lakes of the DT and $\mathrm{FH}$ regions are registered by the Ramsar convention and as Natura 2000 sites; however, lakes in these regions were not appointed and selected as waterbodies according to Water Framework Directive (EC 2000) because their surface areas rarely exceed the 50 ha threshold. Nevertheless, their significance cannot be measured by their size.

Changing agricultural methods, abandoning reduction of potential supply waters, and retaining water on the area can ensure the existence of these habitats (VGT 2009) and preserve the natural hydroperiod. Man-made (fresh) water supply as a replacement for natural groundwater sources would destroy the wildlife of these saline lakes.

Recent management of the saline lakes in the FH region was implemented for habitat restoration with a focus on the conservation of waterfowl (Comín et al. 1999) and beef cattle to maintain their populations (Korner 2012), which could result in losing the special saline character of the lakes of this group. Because this characteristic could be maintained by applying a different kind of conservation treatment, management efforts must consider the natural water coverage with simulation of natural water level fluctuations (Williams 2002) both seasonally and interannually (Talling 2001). Lack of natural salinization processes can lead to a number of floristic and faunistic changes in closed-basin lakes (Fritz et al. 2010). The typical saline diatom species are completely missing from lakes in FH1, and only one dominant species (Entomoneis paludosa var. subsalina) indicates the original or theoretically potential status. The presence of another species, Nitzschia palea, in the FH1 group is also reassuring because this species is defined as a characteristic species of saline lakes (Blinn 1993), although it is also common in freshwaters (Lange-Bertalot 2013). The dominant Achnanthidium minutissimum, however, is associated with electrolyte-poor environments at different pH (van Dam et al. 1994, Kovács et al. 2006) and trophic levels (Lange-Bertalot 2013).

Two saline lakes (Neubruch and Zicklacke in Austria) in the area were outliers from their own FH region, and they more closely resembled samples from the DT region because their bicarbonate content and COD were higher than characteristic in the FH region. Status assessment and evaluation of these 2 lakes may follow the method used in the DT region.

Threats to and impacts on saline lakes from anthropogenic activities involve special requirements for sustainable management. Development of management guidelines is difficult because experiences are scarce compared to freshwater lakes (De Bernardi et al. 1996). Both local and international management and conservation are needed to protect the natural character of these alkaline, saline lakes. Differences in hydrological patterns strongly determine the seasonal and long-term changes in salinity (Williams 2002), which should be considered during their maintenance. 


\section{Acknowledgements}

We thank Alois Herzig, Kata Karádi-Kovács, and András Ambrus for their help in the field. The statistical assistance of Veronika Bókony and Dénes Schmera is also gratefully acknowledged. Publication of Csilla Stenger-Kovács based on this research was supported in the framework of personal support system for researchers by the European Union and the State of Hungary, co-financed by the European Social Fund in the Framework of TÁMOP 4.2.4. A/2-11-1-2012-0001 'National Excellence Program.' Supply of equipment and infrastructure was financed by the National Scientific Research Foundation OTKA K81599 and by the TÁMOP-4.2.2.A-11/1/KONV2012-0064 'Effect of extreme weather events.'

\section{References}

Ács É, Buczkó K, Lakatos G. 1991. A Velencei-tó és a Fertő nádbevonatának összehasonlító algológiai elővizsgálata. Bot Közl. 78:95-111.

Admiraal W, Peletier H, Brouwer T. 1984. The seasonal succession patterns of diatom species on an intertidal mudflat: an experimental analysis. Oikos. 42:30-40.

Alcocer J, Escobar E. 1990. The drying up of the Mexican Plateau axalapazcos. Salinet. 4:44-46.

Alvial I, Cruces F, Araneda A, Grosjean M, Urrutia R. 2008. Estructura comunitaria de diatomeas presents en los sedimentos superficiales de ocho lagos andinos de Chile central. Rev Chil Hist Nat. 81:83-94.

[APHA] American Public Health Association. 1998. Standard methods for the examination of water and wastewater. Baltimore (MD): United Book Press.

Bhattacharyya P, Volcani BE. 1980. Sodium-dependent silicate transports in the apochlorotic marine diatom Nitzschia alba. P Natl Acad Sci USA. 77:6386-6390.

Blanchet FG, Legendre P, Borcard D. 2008. Forward selection of explanatory variables. Ecology. 89:2623-2632.

Blanco S, Álvarez-Blanco I, Cejudo-Figueiras C, De Godos I, Bécares E, Muñoz R, Guzman HO, Vargas VA, Soto R. 2013. New diatom taxa from high-altitude Andean saline lakes. Diatom Res. 28:13-27.

Blinn DW. 1990. The diatom flora of Lake Eyre South; a large episodically filled salt lake in South Australia. Hydrobiologia. 210:101-104.

Blinn DW. 1993. Diatom community structure along physicochemical gradients in saline lakes. Ecology. 74:1246-1263.

Boros E. 1999. A magyarországi szikes tavak és vizek ökológiai értékelése. Acta Biol Debr Oecol Hung. 9:13-80.

Boros E, Bánfi Sz, Forró L. 2006 Anostracans and microcrustaceans as potential food sources of waterbirds on sodic pans of the Hungarian plain. Hydrobiologia. 567:341-349.

Boros E, Forró L, Gere G, Kiss O, Vörös L, Andrikovics S. 2008. The role af aquatic birds in the regulation of trophic relationships of continental soda pans in Hungary. Acta Zool Acad Sci Hung. 54:189-206.
Boros E, Vörös L. 2010. A magyarországi szikes tavak sótartalma és ionösszetétele. Acta Biol Debr Oecol Hung. 22:37-51.

Borsodi AK, Knáb M, Czeibert K, Márialigeti K, Vörös L, Somogyi B. 2013. Planktonic bacterial community composition of an extremely shallow soda pond during a phytoplankton bloom revealed by cultivation and molucular cloning. Extremophiles. 17:575-584.

Bradbury JP, Forester RM, Thompson RS. 1989. Late Quaternary paleolimnology of Ealker Lake, Nevada. J Paleolimnol. 1:249-267.

Buczkó K. 1986. A comperative study of the periphytic algae on three different flower plantt species in Lake Hidegségi Fertő, Hungary. Studia Bot Hung. 19:63-71.

Buczkó K, Ács É. 1996-1997. Zonation of periphytic algae in two Hungarian shallow lakes (Lake Velence and Fertő). Acta Bot Hung. 40:21-34.

Cholnoky B. 1929. Adnotationes criticae ad floram Bacillarium Hungariae. IV. Floristisch-ökologische Bacillarien Untersuchungen in den südlichen Teilen der ungarischen Tiefebene (Alföld). Magyar Bot Lapok. 28:100-155.

Cognetti G, Maltagliati F. 2000. Biodiversity and adaptive mechanisms in brakish water fauna. Mar Pollut Bull. 40:7-14.

Comín FA, Cabrera M, Rodó X. 1999. Saline lakes: integrating ecology into their managment future. Hydrobiologia. 395/396:241-251.

[CEN] Comité Européen de Normalisation. 2003. Water quality guidance standard for the routine sampling and pretreatment of benthic diatoms from rivers. EN 13946:2003, Geneva. 14 p.

Cox EJ. 1996. Identification of freshwater diatoms from live material.. Weinheim (Germany): Chapman \& Hall Press.

Cuthbert ID, del Giorgio P. 1992. Toward a standard method of measuring colour in freshwater. Limnol Oceanogr. 37:1319-1326.

Dargám RM. 1995. Geochemsitry of waters and brines from the Salinas Grandes basin, Córdoba, Argentina. I. Geomorphology and hydrochemical characteristics. Int J Salt Lake Res. 3:137-158.

De Bernardi R, Calderoni A, Mosello R. 1996. Environmental problems in Italian lakes, and lakes Maggiore and Orta as successful examples of correct managment leading to restoration. Verh Internat Verein Limnol. 26:123-138.

De Deckker P. 1988. Biological and sedimentary facies of Australian salt lakes. Palaeogeogr Palaeoecol. 62:237-270.

Donászy E, Hortobágyi T, Kárpáti I, Megyeri J, Pénzes A, Szemes G, Varga L. 1959. Das Leben des Szelider Sees. Die Binnengewässer Ungarns I. Limnologische Studien an einem natriumkarbonatchloridhaltigen See des ungarischen Alföld. Akadémia Kiadó, Budapest.

Dufrêne M, Legendre P. 1997. Species assemblages and indicator species: the need for a flexible asymmetrical approach. Ecol Monogr. 67:345-366.

[EC] European Commission. 2000. Directive of the European Parliament and of the Council 2000/60/EC Establishing a Framework for community action in the field of water policy. European Commission, PECONS 3639/1/100 Rev 1, Luxembourg.

Eloranta PV. 1982. Periphyton growth and the diatom community structure in a cooling water pond. Hydrobiologia. 96:253-265.

Eugster HP, Jones BF. 1979. Behavior of major solutes during closedbasin brine evolution. Am J Sci. 279:609-631. 
Fehér G. 2010. Kiskunsági fehér és barna vizü szikesek algaflórája. Acta Biol Debr Oecol Hung. 22:121-137.

Fehér G, Schmidt A. 2003. Kiskunsági szikes tavak (KNPII) algológiai vizsgálata. Term Közl. 10:163-176.

Fritz SC, Cumming BF, Gasse F, Laird KR. 2010. Diatoms as indicators of hydrologic and climatic change in saline lakes. In: Stroemer F, Smol JP, editors. The diatoms: applications for the environmental and earth Sciences. Cambridge (NY): Cambridge University Press. p. 186-208.

Gasse F. 1986a. East African diatoms. Taxonomy, ecological distribution. Biblioth Diatomol. 11. Stuttgart (Gemany): J. Cramer.

Gasse F. 1986b. East African diatoms and water pH. In: Smol JP, Battarbe RW, Davis RB, Merilainen J, editors. Diatoms and lake acidity. Dotrecht (Germany): Dr. W. Junk.

Gasse F, Barker P, Gell PA, Fritz SC, Chalie F. 1997. Diatom-inferred salinity in palaeolakes: an indirect tracer of climate change. Quat Sci Rev. 16:547-563.

Gottschalk S, Kahlert M. 2012. Shifts in taxonomical and guild composition of littoral diatom assemblages along environmnetal gradients. Hydrobiologia. 694:41-56.

Grimes JA, Rushforth R. 1982. Diatom of recent bottom sediments of Utah Lake, Utah, U.S.A. Bibl Phycol. 55:1-179.

Grunow A. 1860. Über neue oder ungenügend gekannte Algen. Verh Zool-Bot Ges Wien. 10:503-582.

Grunow A. 1862. Die österrischen Diatomaceen nebst Anschlu $\beta$ einiger neuer Arten von anderen Lokaitäten und einer kritischen Übersicht der bisher bekannten Gattungen. Verh Zool-Bot Ges Wien. 12:315-472, 545-588.

Grunow A. 1863. Über einige neue und ungenügend bekannte Arten und Gattungen von Diatomaceen. Verh Zool-Bot Ges Wien. 13:137-162.

Hammer UT. 1986. Saline lake ecosystems of the World. The Hague (Netherlands): Dr. W. Junk.

Hammer UT. 1990. The effects of climatic change on the salinity, water levels and the biota of Canadian prairie saline lakes. Verh Internat Verein Limnol. 24:321-326.

Hammer UT, Shamess J, Haynes RC. 1983. The distribution and abundance of algae in saline lakes of Saskatchewan, Canada. Hydrobiologia. 105:1-26.

Harper DM, Childress RB, Harper MM, Boar RR, Hickleyv P, Mills SC, Otieno N, Vareschi E, Nasirwa O, Mwatha WE, et al. 2003. Aquatic biodiversity and saline lakes: Lake Bogoria National Reserve, Kenya. Hydrobiologia. 500:259-276.

Hickman M. 1982. The removal of a heated water discharge from a lake and the effect upon an epiphytic algal community. Hydrobiologia. 87:21-32.

Horváth Z, Vad CF, Tóth A, Zsuga K, Boros E, Vörös L, Ptacnik E. 2013a. Opposing patterns of zooplankton diversity and functioning along a natural stress gradient: when the going gets tough, the tough get going. Oikos. doi: 10.1111/j.1600-0706.2013.00575.x

Horváth Z, Vad CF, Vörös L, Boros E. 2013b. Distribution and conservation status of fairy shrimps (Crustacea: Anostraca) in astatic soda pans of the Carpathian basin: the role of local and spatial factors. $J$
Limnol. 72:103-116.

Horváth Z, Vad CF, Vörös L, Boros E. 2013c. The keystone role of anostracans and copepods in European soda pans during the spring migration of waterbirds. Freshwater Biol. 58:430-440.

Hustedt F. 1959. Die Diatomeenflora des Neusiedler Sees im österreichischen Burgenland. Oesterr Bot Z. 106:390-430.

Ionescou V, Năstăsescu M, Spiridon L, Bulgăreanu VAC. 1998. The biota of Romanian lakes on rock salt bodies: a review. Int J Salt Lake Res. 7:45-80.

King L, Clarke G, Bennion H, Kelly M, Yallop M. 2006. Recommendations for sampling littoral diatoms in lakes for ecological status assessment. J Appl Phycol. 18:15-25.

Kiss I. 1971. A meteorpapiros és az alatta kialakuló Cyanophyta tömegprodukciók viszgálata a Szeged-környéki, a Dél-Alföldi és a Duna-Tisza közi szikes tavakban. Acta Acad Paed Szegediensis. 1971:33-57.

Kiss I. 1974. Három Bugac-környéki szikes-tó mikroflórájának és mikrovegetációjának összehasonlító vizsgálata. Acta Acad Paed Szegediensis. 1974:3-38.

Kiss I. 1975. A Fülöpháza-környéki szikes tavak, a Szappanos-szék, a Zsíros-szék, a Hattyús-szék és a Kondor-tó mikroflórájának és mikrovegetációjának összehasonlító vizsgálata. Acta Acad Paed Szegediensis. 1975:3-35.

Kiss I. 1976. Magyarország szikes tavaiban végzett hidrológiai és algológiai vizsgálataim áttekintése. Acta Acad Paed Szegediensis. 1976:63-80.

Kiss I. 1978. A szabadszállási szikes tavak algaflórájának és egyes taxonok ozmotikus károsodásának viszgálata. Acta Acad Paed Szegediensis. 1978:63-80.

Koçer MAT, Şen B. 2012. The seasonal succession of diatoms in phytoplankton of a soda lake (Lake Hazar, Turkey). Turk J Bot. 36:738-746.

Korner I. 2012. Gyepek természetvédelmi kezelése legeltetéses szarvasmarhatartással. In: Kárpáti L, Fally J, editors. Fertő-HanságNeusiedler See-Seewinkel Nemzeti Park. Monografikus tanulmányok a Fertő és a Hanság vidékéről. Szaktudás Kiadó Ház, Budapest. p. 242-249.

Kovács C, Kahlert M, Padisák J. 2006. Benthic diatom communities along $\mathrm{pH}$ and $\mathrm{TP}$ gradients in Hungarian and Swedish streams. J Appl Phycol. 18:105-117.

Kürthy A, Somogyi B, Székely Gy, Dragoş N, Márialigeti K, Bartha Cs, Vörös L. 2012. A vízalatti fény spektrális összetételének hatása sekély tavak pikoplanktonjára. Hidr Közl. 92:49-52.

Langbein WB. 1961. Salinity and hydrology of closed lakes. Washington (DC): US Geological Survey, US Govt. Printing Office, Prof Paper 412.

Lange-Bertalot H. 2013. Diatomeen im Süsswasser-Benthos von Mitteleuropa. Königstein (Germany): Koeltz Scientific Books.

Legendre P, Gallagher ED. 2001. Ecologically meaningful transformations for ordination of species data. Oecologia. 129:271-280.

Legendre P, Legendre L. 1998. Numerical ecology. Amsterdam (Netherlands): Elsevier Science B.V.

Leterme SC, Ellis AV, Mitchell JG, Buscot MJ, Pollet T, Schapira M, 
Seuront L. 2010. Morphological flexibility of Cocconeis placentula (Bacillariophyceae) nanostructure to changing salinity levels. J Phycol. 46:715-719.

Leterme SC, Prime E, Mitchell J, Brown MH, Ellis AV. 2013. Diatom adaptability to environmental change: a case study of two Cocconeis species from high-salinity areas. Diatom Res. 28:29-35.

Moss B. 1994. Brakish and freshwater shallow lakes - different systems or variations on the same theme? Hydrobiologia. 275/276:1-14.

Moss B, Hering D, Green AJ, Aidoud A, Becares E, Beklioglu M, Bennion H, Boix D, Brucet S, Carvalho L, et al. 2009. Climate change and future of freshwater biodiversity in Europe: a primer for policy-makers. Freshwater Rev. 2:103-130.

Nagy L, Péterfi LS, Stefan L. 2008. Preliminary data on the diatom communities from "Lacul Sulfuros" ("Lake No. 6") near Turda (Cluj, County, Romania). Contrib Bot. 43:105-111.

Oduor SO, Schagerl M. 2007. Temporal trends of ionic contents and nutrients in three Kenyan Rift Valley saline-alkaline lakes and their influence on phytoplankton biomass. Hydrobiologia. 584:59-68.

Oksanen J, Blanchet FG, Kindt R, Legendre P, Minchin PR, O’Hara RB. 2012. Vegan: community ecology Package. R package version 2.0-7. Available from: http://cran.r-project.org/web/packages/vegan/ index.html

Oren A. 1999. Microbiology and biogeochemstry of hypersaline environments. Boca Raton (FL): CRC press.

Padisák J. 1999. Checklist of aquatic algae found in the Kiskunság National Park and in the Danube-Tisza interfluve. The flora of the Kiskunság National Park, Cryptogams. 9-146, Magyar Természettudományu Múzeum, Budapest.

Padisák J. 2003. Phytoplankton. In: O’Sullivan PE, Reynolds CS, editors. The lakes handbooks. Volume 1. Limnology and Limnetic Ecology. Blackwell Publishing. p. 251-308.

Padisák J, Dokulil M. 1991. A planktonikus diatómák mennyiségének szezonális és hosszú távú (1968-1990) változásai a Fertőben (Ausztria/Magyarország). Bot Közl. 78:77-85.

Padisák J, Dokulil M. 1994. Meroplankton dynamics in a saline, turbulent, turbid shallow lake (Neusiedlersee, Austria and Hungary). Hydrobiologia. 289:23-42.

Pálffy K, Felföldi T, Mentes A, Horváth H, Márialigeti K, Boros E, Vörös L, Somogyi B. 2013. Unique picoeukaryotic algal community under multiple environmental stress conditions in a shallow, alkaline pan. Extremophiles. doi 10.1007/s00792-013-0602-0

Pantocsek J. 1912. A Fertő tó kovamoszat viránya (Bacillaririae Lacus Peisonis). Pozsony.

Passy SI. 2007. Diatom ecological guilds display distinct and predictable behavior along nutrient and disturbance gradients in running waters. Aquat Bot. 86:171-178.

Patrick R. 1969. The effects of increasing light and temperature on the structure of diatom communities; [cited 12. Sep 2013]. Available from: http://aslo.org/lo/toc/vol_16/issue_2/0405.pdf

Potapova M. 2011. Patterns of diatom distribution in relation to salinity. In: Seckbach J, Kociolek JP, editors. The diatom world. Cellular origin, life in extreme habitats and astrobiology, Vol. 19. New York: Springer. p. 313-333.
R Development Core Team 2010. R: A language and environment for statistical computing, reference index version 2.11.0. R Foundation for Statistical Computing, Vienna, Austria. ISBN 3-900051-07-0. Available from: http://www.R-project.org

Reed JM. 1998. A diatom-conductivity transfer function for Spanish salt lakes. J Paleolimnol. 19:399-416.

Rimet F, Bouchez A. 2011. Use of diatom life-forms and ecological guilds to assess pesticide contamination in rivers: Lotic mesocosm approaches. Ecol Indic. 11:489-499.

Rusznyák A, Tóth EM, Schumann P, Sproer C, Makk J, Szabó G, Vladár P, Márialigeti K, Borsodi AK.2011. Cellulomonas phragmiteti sp. nov., a cellulolytic bacterium isolated from reed (Phragmites australis) periphyton in a Hungarian shallow soda pond. Int J Syst Evol. 61:1662-1666.

Sabbe K, Verleyen E, Hodgson DA, Vanhoutte K, Vyverman W. 2003. Benthic diatom flora of freshwater and saline lakes in the Larsemann Hills and Rauer Islands, East Antarctica. Antarct Sci. 15:227-248.

Saros JE, Fritz SC. 2000. Changes in the growth rates of saline-lake diatoms in response to variation in salinity, brine type and nitrogen form. J Plankton Res. 22:1071-1083.

Saros JE, Fritz SC. 2002. Resource competition among saline-lake diatoms under varying N/P ratio, salinity and anion composition. Freshwater Biol. 47:87-95.

Schmidt A. 2003. Kiskunsági szikes tavak (KNP II) vízkémiai és algológiai vizsgálata (1998-1999). Hidr Közl. 81:455-456.

Schmidt A, Fehér G. 1996. Adatok Dél-Magyarországi vizek algáinak ismeretéhez III. Bot Közl. 83:121-138.

Schobert B. 1974. The influence of water stress on the metabolism of diatoms. I. Osmotic resistance and proline accumulation in Cyclotella meneghiniana. Z. Pflanzenphysiol. 74:106-120.

Servant-Vildary S. 1984. Les Diatomées des lacs sursalés Boliviens. Sous-classe Pennatophycidées, 1- Famille des Nitzschiaceé. Cah ORSTOM. 14(1):35-53.

Servant-Vildary S, Roux M. 1990. Multivariate analysis of diatoms and water chemistry in Bolivian saline lakes. Hydrobiologia. 197:267290.

Shiklomanov IA. 1990. Global water resources. Nat Res. 26:34 43.

Simon S, Mádl-Szőnyi J, Müller I, Pogácsás G. 2011. Conceptual model for surface salinization in an overpressured and a superimposed gravity flow field, Lake Kelemen-szék area, Hungary. Hydrogeol J. 19:707-711.

Somogyi B, Felföldy T, Dinka M, Vörös L. 2011a. Periodic picophytoplankton predominance in a large shallow alkaline lake (Lake Fertö, Neusiedlersee). Ann Limnol Int J Lim. 46:9-19.

Somogyi B, Felföldi T, Márialigeti K, Vörös L. 2012. Sekély tavaink téli eukarióta pikoalgái. Hidr Közl. 92:49-52.

Somogyi B, Herzig A, Németh B, Vörös L. 2011b. Szervetlen lebegőanyagok hatása sekély tavak fitoplankton struktúrájára (különös tekintettel a pikoplanktonra). Hidr Közl. 91:72-74.

Sondergaard ME, Jeppesen P, Kristensen P, Sortkjaer O. 1990. Interactions between sediment and water in a shallow and hypertrophic lake: a study on phytoplankton collapses in Lake Sobygard, Denmark. Hydrobiologia. 191:139-148. 
Spaulding SA, McKnight DM. 1999. Diatoms as indicators of environmental change in Antarctic freshwaters. In: Stroemer F, Smol JP, editors. The diatoms: applications for the environmental and earth sciences. Cambridge (NY): Cambridge University Press. p. 245-263.

Stenger-Kovács C, Lengyel E, Crossetti LO, Üveges V, Padisák J. 2013. Diatom ecological guilds as indicators of temporally changing stressors and disturbances in the small Torna-stream, Hungary. Ecol Indic. 24:138-147.

Sze P, Kingsbury JM. 1972. Distribution of phytoplankton in polluted saline lakes, Onondaga Lake, New York. J Phycol. 8:25-37.

Szemes G. 1959. Die horizontale und vertikale Verbreitung der Bacillariophyceen im offenen Wasser des Szelider Sees. Systematische und floristisch-ökologische Bearbeitung von Bacillariophyceen des Szelider-Sees. In: Donászy E, editor. Das Leben des Szelider Sees. Akadémiai Kiadó, Budapest. p. 251-273, 301-360.

Szépszó G. 2008. Regional change of climate extremes over Hungary based on different regional climate models of the PRUDENCE project. Quarterly Journal of the Hungarian Meteorological Service. Időjárás. 112:265-284.

Talling JF. 2001. Environmental controls on the functioning of shallow tropical lakes. Hydrobiologia. 458:1-8.

Tibby J, Gell PA, Fluin J, Sluiter IRK. 2007. Diatom-salinity relationship in wetlands: assessing the influence of salinity variability on the development of inference models. Hydrobiologia. 591:207-218.

Trobajo R, Cox JE, Quintana XD. 2004. The effects of some environmental variables on the morphology of Nitzschia frustulum (Bacillariophyta), in relation its use as bioindicators. Nova Hedwigia. 79:433-445.

Trobajo R, Rovira L, Mann DG, Cox EJ. 2011. Effects of salinity on growth and on valve morphology of five estuarine diatoms. Phycol Res. 59:83-90.

Tuchman ML, Theriot E, Stoermer EF. 1984. Effects of low level salinity concentrations on the growth of Cyclotella meneghiniana Kütz. (Bacillariophyta) .Arch Protistenkd. 128:319-326.

Tuite CH. 1981. Standing crop densities and distribution of Spirulina and benthic diatoms in East African alkaline saline lakes. Freshwater Biol. 11:345-360.

Uherkovich G. 1965. Beiträge zur Kenntnis der Algenvegetation der Natron- bzw. Soda-szik Gewässer Ungarns I. Acta Bot Hung. 11:263-280.

Uherkovich G. 1969. Beiträge zur Kenntnis der Algenvegetation der Natron- bzw. Soda-szik Gewässer Ungarns. Über die Algen des Teiches Öszeszék. Hydrobiologia. 33:250-288.

Uherkovich G. 1970. Beiträge zur Kenntnis der Algenvegetation der Natron- bzw. Soda-szik Gewässer Ungarns. III. Das Phytoplankton der Natronteiches bei Kunfehértó. Acta Bot. 16:405-426.
Van Dam H, Mertens A, Sinkeldam J. 1994. A coded checklist and ecological indicator values of freshwater diatoms and ecological indicator values of freshwater diatoms from Netherland. Neth $\mathrm{J}$ Aquat Ecol. 28:117-133.

Váradi Z, Fehér G. 2010. Kiskunsági szikes tavak kémiai vizsgálata. [Chemical investigation of some soda ponds located in the Kiskunság Area (Hungary)]. Acta Biol Debr Oecol Hung. 22:53-74.

V.-Balogh K, Németh B, Vörös L. 2009. Specific attenuation coefficients of optically active substances and their contribution to the underwater ultraviolet and visible light climate in shallow lakes and ponds. Hydrobiologia. 632:91-105.

V.-Balogh K, Németh B, Vörös L. 2010. Szervesanyagok magyarországi fehér vízü szikes tavakban. Organic substances in Hungarian turbid soda ponds. Acta Biol Debr Oecol Hung. 22:75-86.

[VGT] Vízgyüjtő Gazdálkodási Terv 2009. River basin management plan of Hungary; [cited 20 Sept 2013]. Available from: http://www. vizeink.hu/files/vizeink.hu_0326_Orszagos_VGT_kezirat_aug.pdf

Vörös L, Boros L. 2010. Nodularia willei Gardn. Tömegprodukció: a planktonikus és bentonikus elsődleges termelés peremfeltételei egy kiskunsági szikes tóban (Kelemen-szék). Acta Biol Debr Oecol Hung. 22:139-152.

Vrieling EG, Sun Q, Tian M, Kooyman PJ, Gieskes WWC, van Santen RA, Sommerdijk NAJM. 2007. Salinity dependent diatom biosilification implies an important role of external ionic strength. P Natl Acad Sci USA. 104:10441-10446.

Wetzel RG. 1983. Limnology. Philadelphia (PA): Saunders College Publishing. 767 p.

Wetzel RG, Likens GE. 2000. Limnological analyses. New York: Springer-Verlag.

Wilson SE, Cumming BF, Smol JP. 1994. Diatom-salinity relationships in 111 lakes from the Interior Plateau of British Columbia, Canada: the development of diatom based models for paleosalinity reconstructions. J Paleolimnol. 12:197-221.

Williams WD. 1986. Limnology, the study of inland waters: a comment on the perceptions of studies of salt lakes. Past and present. In: De Decker P, Williams WD, editors. Limnology in Australia. Dordrecht (Germany): Dr. W. Junk. p. 471-486.

Williams WD. 1993. Conservation of salt lakes. Hydrobiologia. 267:291-306.

Williams WD. 2002. Environmental threats to salt lakes and the likely status of inland saline ecosystems in 2025. Environ Conserv. 29:154-167. 